\title{
Antibiotic Resistance Patterns among Gram-negative Bacteria from Patients with Urinary Tract Infection at a Healthcare Center in Ekiti-State, Nigeria
}

\author{
Ajayi A. O., ${ }^{1, *}$, Osanyinlusi S. A. ${ }^{1}$, Ogeneh B. ${ }^{1}$, Ojerinde O. A. ${ }^{2}$, Oladeji S. J. \\ ${ }^{1}$ Department of Microbiology, Federal University Oye-Ekiti, Ekiti-State, Nigeria \\ ${ }^{2}$ Laboratory Unit, University Health Center, Federal University Oye-Ekiti, Ekiti-State, Nigeria \\ *Corresponding author: ayodele.ajayi@fuoye.edu.ng \\ Received January 10, 2019; Revised March 15, 2019; Accepted March 22, 2019
}

\begin{abstract}
Urinary Tract Infections (UTIs) are huge health burden. This study determined the current incidence of antibiotic resistance among Gram-negative bacteria from patients with UTI at a health center in Ado Ekiti, Nigeria. One hundred and twenty two mid-stream urine samples were collected and cultured. Sixty-four samples (52.4\%) grew significant bacteria. Gram-negative bacterial colonies were picked per plate, identified and tested for

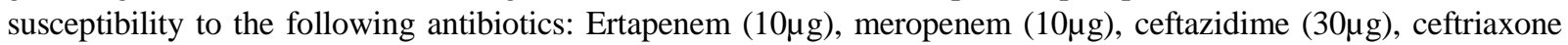
$(30 \mu \mathrm{g})$, gentamicin $(10 \mu \mathrm{g})$, ampicillin $(10 \mu \mathrm{g})$, tetracycline $(30 \mu \mathrm{g})$, norfloxacin $(10 \mu \mathrm{g})$ and pefloxacin $(5 \mu \mathrm{g})$. Thirty-nine isolates were selected for extended spectrum beta-lactamase production using the double disk synergy test. All the bacteria were tested for biofilms and haemolysis. Sixty-four Gram-negative bacterial isolates were recovered from 64 samples. The bacteria recovered included $K$. pneumonia, K. oxytoca, P. vulgaris, E. coli, $P$. mirabilis and $P$. aeruginosa. Overall, the bacteria showed the highest resistance to ampicillin 60/64 (94.5\%) and least resistance to meropenem 18/64 (28.1\%). All the bacteria tested for ESBL production were confirmed as ESBL producers. Twenty-two (34.3\%) isolates were strong biofilm producers while 19 isolates were haemolytic (29.7\%). These findings have serious implications to medical care and public health. Strict antibiotic stewardship should be enforced.
\end{abstract}

Keywords: Gram-negative bacteria, UTIs, antibiotic resistance, biofilm

Cite This Article: Ajayi A. O., Osanyinlusi S. A., Ogeneh B., Ojerinde O. A., and Oladeji S. J., "Antibiotic Resistance Patterns among Gram-negative Bacteria from Patients with Urinary Tract Infections at a Healthcare Center in Ado-ekiti, Nigeria." American Journal of Microbiological Research, vol. 7, no. 2 (2019): 37-44. doi: 10.12691/ajmr-7-2-1.

\section{Introduction}

Urinary tract infections (UTIs) are microbial invasion of the urinary tract, including the kidneys, urethra, bladder and other related anatomical sites [1]. Globally, UTIs are the most common microbial infections in humans with significant public health burden in terms of morbidity, mortality and financial costs [2]. Furthermore, an estimated 150 million people are affected by UTIs with diverse epidemiological characteristics across the globe [3]. Some Africa wide studies have also confirmed that UTIs are common problem in Africa, including Nigeria [4]. Although systematic data are unavailable for Nigeria, several independent studies have confirmed that UTIs are common, in different strata of the population, including women, outpatients and inpatients [5,6].

Freshly voided urine from the kidneys is sterile; but significant number of bacterial colonies could be detected following microbial invasion and colonization of the urinary tract [2]. Accordingly, UTI is confirmed by the bacterial count of $\geq 10^{5} \mathrm{cfu} / \mathrm{mL}$ in freshly voided mid- stream urine [7]. In qualitative bacteriological terms, the most predominant bacteria implicated in UTIs include E. coli, S. aureus, K. pneumoniae, E. aerogenes, $P$. aeruginosa, S. faecalis and Enterobacter spp. [1]. The clinical indications of UTIs include cystitis - which is bacterial colonization of the bladder, pyelonephritis and uretheritis which affects the kidneys and urethra respectively [2].

Previous studies have established that Nigeria has a share in the burden and prevalence of UTIs in different states and municipalities [8,9,10,11]. It was also reported that the UTI prevalence of 54\% among pregnant women in Akwa metropolis in Southeastern Nigeria [11]. Similarly, a prevalence of $47.5 \%$ among 80 freshly voided urine samples collected at an antenatal clinic [12]. UTIs have also been reported among children and adolescents [13] even though with lower prevalence as compared with studies involving pregnant and sexually active women. However, there are indications that the epidemiological features of infectious diseases, including UTIs, vary across different locations and clinical settings at different periods; making it imperative to know the current epidemiological characteristics of UTIs in selected 
locations [14,15]. This knowledge is crucial for surveillance and antimicrobial stewardship. Unfortunately, there is lack of coordinated surveillance efforts and therefore, surveillance of infections is considered an imperative to achieve this purpose.

The predominance of UTIs has necessitated the increased use of antibiotics to treat and prevent UTIs in core clinical and community settings [15]. However, this has always heightened the risk of emergence of antibiotic resistant bacteria in UTIs leading to a recent surge in the incidence of antibiotic resistant UTIs [2]. Common treatment regimens for UTIs include amoxicillin-clavulante, nitrofurantoin, beta-lactams, fluoroquinolones and trimethropin-sulfamethoxazole [16]. High incidence of extended spectrum beta-lactamase (ESBL) producing bacteria from UTIs has been confirmed by different studies $[17,18]$. This phenomenon has been linked with increased antibiotic treatment failures, hospitalizations and complications in clinical settings $[19,20]$. Antibiotic resistance among bacteria in community acquired UTIs have also been reported in Nigeria and other developing countries and they are associated with intake of antibiotics without prescription $[17,21,22]$.

This study was carried out determine the current prevalence of multiple antibiotic resistant Gram-negative bacteria and their current antibiotic resistance patterns among individuals who reported at two healthcare facilities in Ekiti-State, South western Nigeria.

\section{Methodology}

\subsection{Study Locations and Sample Collections}

This study was carried out at the tertiary healthcare facility that provides extensive in-and out-patient services for the general populace in Ekiti-State, Nigeria. Ekiti State is located in the southwest geopolitical region with an estimated population of 1 million people. This hospital provides inpatient and outpatient services. Freshly voided midstream urine samples were collected from patients referred to the microbiology laboratory for urine culture and antibiotic sensitivity between February 2018 to June 2018. A total of 122 urine samples were collected of which 64 samples grew significant bacteria. The samples collected spread across inpatients, outpatients and the different hospital units (Figure 1). The demographic details of individuals that reported and submitted urine samples to the microbiology laboratory are given in Table 1. Samples were obtained following necessary ethical approvals from the respective institutions.

Table 1. Demographic details of patients with urine samples growing significant bacteria.

\begin{tabular}{ll}
\hline SEX & \\
\hline MALE & $27(42.2 \%)$ \\
FEMALE & $37(57.8)$ \\
AGE & \\
$\leq 10$ yrs & $1(1.6 \%)$ \\
$11-40$ yrs & $29(43.3 \%)$ \\
$41-70$ yrs & $15(23.4 \%)$ \\
$\geq 70$ yrs & $19(29.7 \%)$ \\
OUTPATIENTS/INPATIENTS & \\
Outpatients & $48(75 \%)$ \\
Inpatients & $16(25 \%)$ \\
\hline
\end{tabular}

\subsection{Culture Procedure}

Ten microliters of each mid-stream urine sample was inoculated separately onto plates containing cysteine lactose electrolyte deficient medium (CLED) and MacConkey agar. Inoculated plates were incubated at $37^{\circ} \mathrm{C}$ for 24 hours. For each urine sample, bacterial colony counts $\geq 10^{5} \mathrm{cfu} / \mathrm{ml}$ on CLED was considered significant. Presumptive colonies were picked from corresponding MacConkey agar plates and sub-cultured onto fresh agar plates to obtain pure colonies. All bacteria were identified using standard biochemical tests [23] and stored on nutrient agar slants for further study.

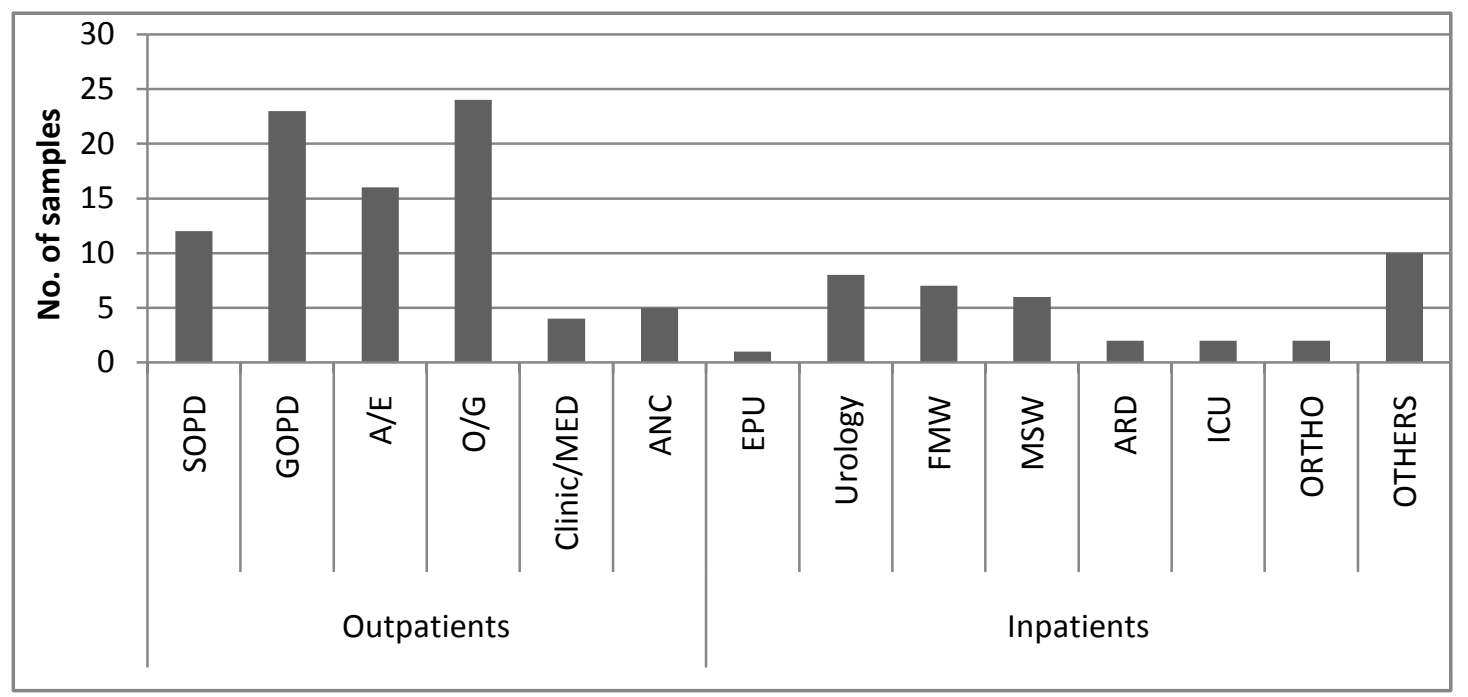

$\mathrm{SOPD}=$ Surgical Out-patient Department GOPD= General Out-patient Department A/E= Accident and Emergency O/G= Obstetrics and Gynaecology ANC=Antenatal Care EPU= Emergency Paediatric MSW= Male Surgical Ward FMW= Female Surgical Ward ARD=Ascites Reinfusion Dialysis ICU= Intensive Care Unit Ortho= Orthopedic. *OTHERS - These are urine samples from patients whose demographic details are not captured in clinical records. 


\subsection{Antibiotic Susceptibility Test}

Antibiotic susceptibility tests were carried out on all bacterial isolates using the disk diffusion method and interpreted according to the guidelines of the Clinical Laboratory Science Institute [14]. The bacterial were grown overnight on sterile Mueller-Hinton agar plates and few colonies were inoculated onto sterile normal saline adjusted to match the 0.5 Turbidity standard. The antibiotic

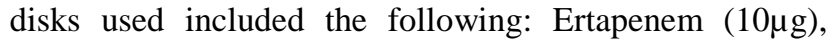
meropenem $(10 \mu \mathrm{g})$, ceftazidime $(30 \mu \mathrm{g})$, ceftriaxone

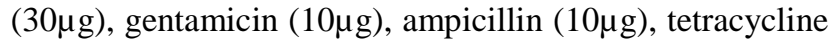

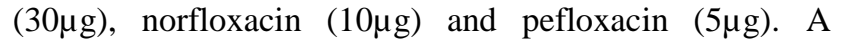
standardized innocula were used to inoculate sterile Mueller-Hinton agar plates and antibiotic disks were placed as appropriate. All plates were incubated at $37^{\circ} \mathrm{C}$ for 24 hours. Plates were checked for zones of inhibition ant classified as resistant using the standard interpretative chart. Multiple drug resistance (MDR) was defined as resistance among the isolates to drugs in two or more different classes of antibiotics. The E. coli ATCC 25922 was used as control for all antibiotic susceptibility tests.

\subsection{Detection of ESBL Producers}

All 39 bacteria that showed reduced susceptibility to either ceftazidime were tested ESBL production using the standard double disk synergy tests. In this test, disks containing amoxicillin-claviculanic acid was placed at the center of inoculated Mueller-Hinton agar plates, surrounded by ceftazidime and ceftriaxone placed $20 \mathrm{~mm}$ equidistant from the amoxicillin-claviculanic disks. Bacteria with enhanced zone of inhibition towards the amoxicillin-claviculaninc acid disk were recognized as ESBL producers.

\subsection{Detection of Biofilm Formation}

For the purpose of this study, the Congo red agar method was used for the detection of biofilm producers among all the bacteria isolated as previously described [25]. The bacteria were grown on agar plates supplemented with Congo red and incubated at $37^{\circ} \mathrm{C}$ for 24 hours. Formation of black crystalline colonies was taken as confirmation for the formation of biofilm among the bacterial isolates. Those with grey colonies were indicative of intermediate biofilm producers while those that appeared red were non-biofilm producers.

\subsection{Detection of Haemolytic Activity}

The hemolytic activity of all the bacteria was detected by culturing the bacteria on Mueller Hinton agar plates supplemented with 5\% sheep blood and incubated at $35^{\circ} \mathrm{C}$ for 24 hours [26]. After incubation, all plates were checked for characteristic alpha and beta hemolytic patterns.

\section{Results}

The urine samples from different units of the hospital were cultured accordingly and different Gram-negative bacteria were obtained. Sixty four out of 122 urine samples collected showed bacteriurea and sixty-four organisms were obtained from the urine samples (Figure 2). The bacteria recovered were $K$. pneumonia, K. oxytoca, P. vulgaris, E. coli, P. mirabilis and $P$. aeruginosa. The distributions of the organisms across the different units is shown in (Table 2) with the SOPD emerging as the unit with the highest number of bacterial isolations. All the bacteria that showed reduced susceptibility to ceftazidime $(<22 \mathrm{~mm})$ were all confirmed to be ESBL producers on the basis of their patterns with the double disk synergy test (Figure 3). Overall, resistance to amplicillin was highest, followed by pefloxacine and gentamicin respectively (Table 3) while resistance to ertapenem and meropenem was least (Table 3). The distribution of the resistance shown to various antibiotics among the different organisms is shown in (Table 4). Multiple antibiotic resistance was defined as resistance to minimum of 3 antibiotics of different classes and 61 (95.3\%) isolates were multi-drug resistant (Table 5) with 28 different resistance patterns were observed (Table 6). Nineteen isolates $(29.7 \%)$ showed some hemolysis (Table 7$)$ while fifty-one isolates $(70.7 \%)$ produced biofilms produced biofilms with different haemolytic patterns (Table 8).

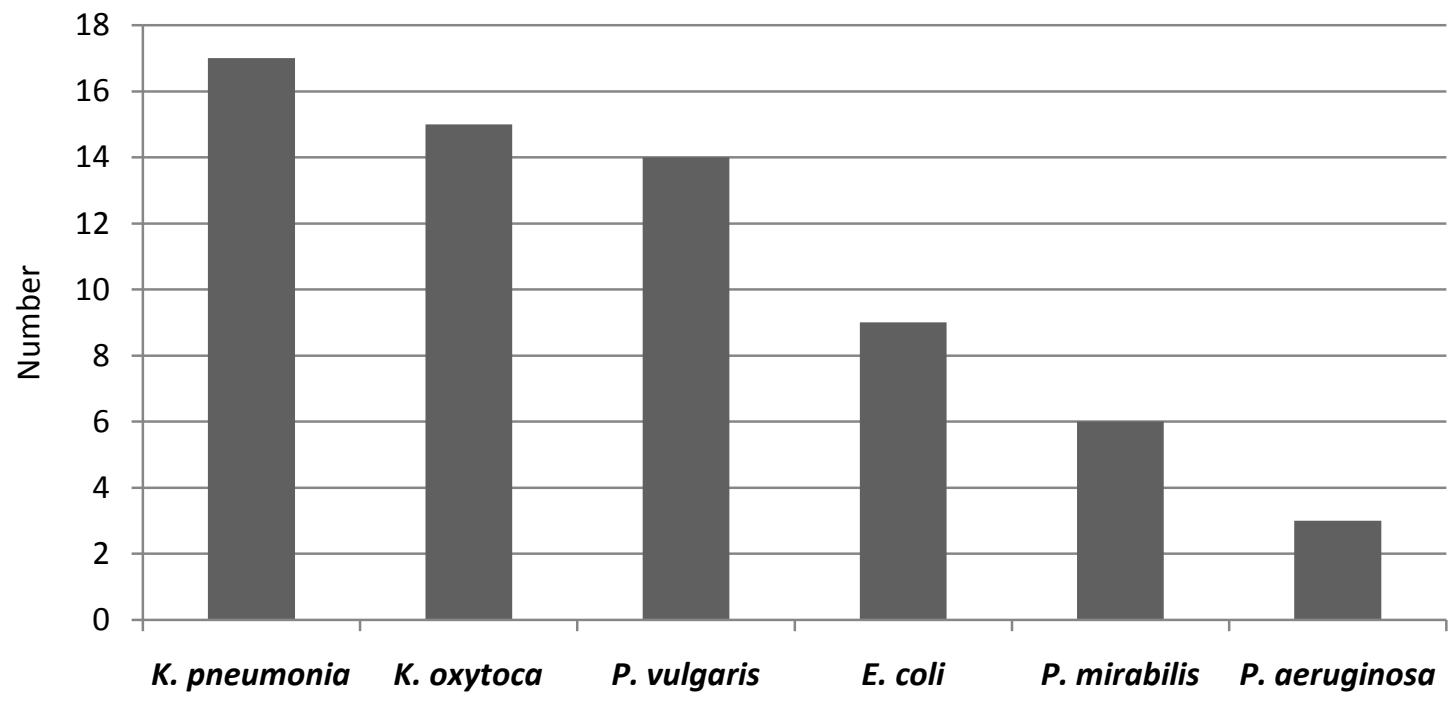

Figure 2. Number of organisms isolated from urine samples $(\mathrm{n}=64)$ 
Table 2. Distribution of organisms by units

\begin{tabular}{|c|c|c|c|c|c|c|}
\hline & $\begin{array}{c}\text { K. pneumonia } \\
(\mathrm{n}=17)\end{array}$ & $\begin{array}{c}\text { K. oxytoca } \\
(\mathrm{n}=15)\end{array}$ & $\begin{array}{c}\text { P. vulgaris } \\
(\mathrm{n}=14)\end{array}$ & $\begin{array}{l}\text { E. coli } \\
(\mathrm{n}=9)\end{array}$ & $\begin{array}{l}\text { P. mirabilis } \\
(\mathrm{n}=6)\end{array}$ & $\begin{array}{c}\text { P. aeruginosc } \\
(\mathrm{n}=3)\end{array}$ \\
\hline \multicolumn{7}{|l|}{ Units } \\
\hline SOPD & $0(0 \%)$ & 4 (26.7\%) & 2 (14.3\%) & 3(33.3\%) & $1(16.7 \%)$ & $0(0 \%)$ \\
\hline GOPD & 5 (29.4\%) & $0(0 \%)$ & 2 (14.3\%) & $0(0 \%)$ & $0(0 \%)$ & $0(0 \%)$ \\
\hline $\mathbf{A} / \mathbf{E}$ & 4 (23.5\%) & $0(0 \%)$ & 4 (28.6\%) & $0(0 \%)$ & $0(0 \%)$ & $0(0 \%)$ \\
\hline O/G & 2 (11.8\%) & 4 (26.7\%) & 2(14.3\%) & 1 (11.1\%) & $3(50.0 \%)$ & $0(0 \%)$ \\
\hline CLINIC & 2 (11.8\%) & $0(0 \%)$ & $0(0 \%)$ & 1 (11.1\%) & $0(0 \%)$ & $0(0 \%)$ \\
\hline ANC & 1(5.9\%) & 2 (13.3\%) & $0(0 \%)$ & $0(0 \%)$ & 1(16.7\%) & 1 (33.3\%) \\
\hline NHIS & $0(0 \%)$ & 1 & $0(0 \%)$ & $2(22.2 \%)$ & $0(0 \%)$ & $0(0 \%)$ \\
\hline EPU & $0(0 \%)$ & 0 & $1(7.1 \%)$ & $0(0 \%)$ & $0(0 \%)$ & $0(0 \%)$ \\
\hline UROLOGY & $0(0 \%)$ & $0(0 \%)$ & $0(0 \%)$ & $0(0 \%)$ & 1(16.7\%) & 1 (33.3\%) \\
\hline MSW & 2 (11.8\%) & 2 (13.3\%) & $0(0 \%)$ & $0(0 \%)$ & $0(0 \%)$ & $0(0 \%)$ \\
\hline FMW & 1 (5.9\%) & 2 (13.3\%) & 1 (7.1\%) & 1(11.1\%) & $0(0 \%)$ & 1 (33.3\%) \\
\hline ARD & $0(0 \%)$ & $0(0 \%)$ & $1(7.1 \%)$ & 1 (11.1\%) & $0(0 \%)$ & $0(0 \%)$ \\
\hline ICU & $0(0 \%)$ & $0(0 \%)$ & $1(7.1 \%)$ & $0(0 \%)$ & $0(0 \%)$ & $0(0 \%)$ \\
\hline
\end{tabular}

Keys: $\mathrm{GOPD}=$ General Out-patient Department, $\mathrm{A} / \mathrm{E}=$ Accident and Emergency, $\mathrm{O} / \mathrm{G}=$ Obstetrics and Gynecology, ANC=Antenatal Care, NHIS= Health Insurance Scheme, EPU= Emergency Paediatric Unit, MSW= Male Surgical Ward, FMW= Female Surgical Ward, ARD=Ascites Reinfusion Dialysis, ICU= Intensive Care Unit.

Table 3. Overall antibiotic susceptibility among isolates

\begin{tabular}{lcc}
\hline Antibiotic & Susceptible (\%) & Resistant (\%) \\
\hline Ertapenem & $38(59.4)$ & $26(40.6)$ \\
Meropenem & $46(71.9)$ & $18(28.1)$ \\
Ceftazidime & $25(39.1)$ & $39(60.9)$ \\
Ceftriaxone & $18(28.1)$ & $46(71.9)$ \\
Gentamicin & $8(12.5)$ & $56(87.5)$ \\
Ampicilin & $4(6.2)$ & $60(93.8)$ \\
Tetracycline & $14(21.9)$ & $50(78.1)$ \\
Norfloxacin & $20(31.2)$ & $44(68.8)$ \\
Pefloxacin & $13(20.3)$ & $51(79.7)$ \\
\hline
\end{tabular}

Table 4. Antibiotic resistance among individual organisms

\begin{tabular}{|c|c|c|c|c|c|c|}
\hline Antibiotic & $\begin{array}{c}\text { K. pneumonia } \\
(\mathrm{n}=17)\end{array}$ & $\begin{array}{c}\text { K. oxytoca } \\
(\mathrm{n}=15)\end{array}$ & $\begin{array}{c}P . \text { vulgaris } \\
(\mathrm{n}=14)\end{array}$ & $\begin{array}{c}\text { E. coli } \\
(\mathrm{n}=9)\end{array}$ & $\begin{array}{l}\text { P. mirabilis } \\
(\mathrm{n}=6)\end{array}$ & $\begin{array}{c}\text { P. aeruginosa } \\
(\mathrm{n}=3)\end{array}$ \\
\hline Ertapenem & $8(47.1 \%)$ & $4(26.7 \%)$ & $6(42.9 \%)$ & $1(11.1 \%)$ & $5(83.3 \%)$ & $2(66.7 \%)$ \\
\hline Meropenem & $6(35.3 \%)$ & $3(20 \%)$ & $4(28.6 \%)$ & $1(11.1 \%)$ & $3(17.7 \%)$ & $1(33.3 \%)$ \\
\hline Ceftazidime & $12(70.6 \%)$ & $9(60 \%)$ & $8(57.1 \%)$ & $5(55.6 \%)$ & $3(17.7 \%)$ & $2(66.7 \%)$ \\
\hline Ceftriaxone & 13 (76.5\%) & $11(73.3 \%)$ & $9(64.3 \%)$ & $5(55.6 \%)$ & $5(83.3 \%)$ & $3(100 \%)$ \\
\hline Gentamicin & $14(82.4 \%)$ & 13 (86.7\%) & 13 (92.9\%) & 8 (88.9\%) & $5(83.3 \%)$ & $3(100 \%)$ \\
\hline Ampicilin & $16(94.1 \%)$ & 15 (100\%) & 12 (85.7\%) & $9(100 \%)$ & $5(83.3 \%)$ & $3(100 \%)$ \\
\hline Tetracycline & 13 (76.5\%) & 13 (86.7\%) & $9(64.3 \%)$ & $9(100 \%)$ & $4(66.7 \%)$ & $2(66.7 \%)$ \\
\hline Norfloxacin & 11 (64.7\%) & 11 (73.3\%) & 8 (57.1\%) & 8 (88.9\%) & $3(50 \%)$ & $3(100 \%)$ \\
\hline Pefloxacin & $15(88.8 \%)$ & $15(100 \%)$ & $12(85.7 \%)$ & $9(100 \%)$ & $6(100 \%)$ & $3(100 \%)$ \\
\hline
\end{tabular}

Table 5. Distribution of multi-drug resistance across isolates

\begin{tabular}{ccccccc}
\hline $\begin{array}{c}\text { No. of drug } \\
\text { groups }\end{array}$ & $\begin{array}{c}\boldsymbol{K} \text {. pneumonia } \\
(\mathbf{n}=\mathbf{1 7})\end{array}$ & $\begin{array}{c}\text { K. oxy } \\
(\mathbf{n}=\mathbf{1 5})\end{array}$ & $\begin{array}{c}\boldsymbol{P} . \text { vul } \\
(\mathbf{n}=\mathbf{1 4})\end{array}$ & $\begin{array}{c}\mathbf{E} \text {. coli } \\
(\mathbf{n}=\mathbf{9})\end{array}$ & $\begin{array}{c}\boldsymbol{P} \text {. } \mathbf{m i r} \\
(\mathbf{n}=\mathbf{6})\end{array}$ & $\begin{array}{c}\boldsymbol{P} \text {. aer } \\
(\mathbf{n}=\mathbf{3})\end{array}$ \\
\hline $\mathbf{3}$ & $1(5.9 \%)$ & $2(13.3 \%)$ & $3(21.4 \%)$ & $1(11.1 \%)$ & $2(3.3)$ & - \\
$\mathbf{4}$ & - & $3(20 \%)$ & $3(21.4 \%)$ & $2(22.2 \%)$ & - & - \\
$\mathbf{5}$ & $7(41.2 \%)$ & $7(46.7 \%)$ & $5(35.2 \%)$ & $4(44.4 \%)$ & - & $2(66.6 \%)$ \\
$\mathbf{6}$ & $7(41.2 \%)$ & $3(20 \%)$ & $2(14.3 \%)$ & $2(22.2 \%)$ & $4(6.6)$ & $1(33.3 \%)$ \\
\hline Total & $\mathbf{1 5}$ & $\mathbf{1 5}$ & $\mathbf{1 3}$ & $\mathbf{9}$ & $\mathbf{6}$ & $\mathbf{3}$ \\
\hline
\end{tabular}

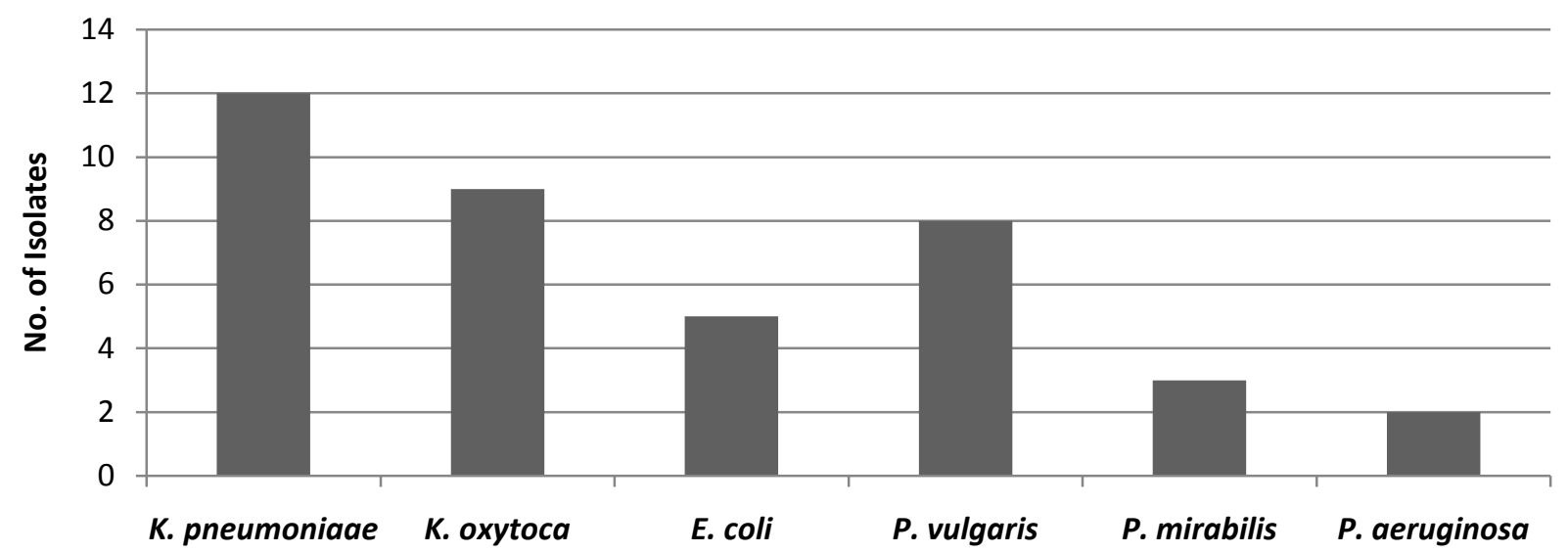

Figure 3. Number of ESBL producing bacteria among samples 
Table 6. Antibiotic resistance patterns among isolates

\begin{tabular}{|c|c|c|c|c|c|c|c|c|}
\hline No. of Antibiotics & Resistance patterns & K. pne & K. oxy & P. vul & E. col & P. mir & P. aer & $\begin{array}{c}\text { Total } \\
\text { N (\%) }\end{array}$ \\
\hline \multirow[t]{2}{*}{2} & Gen-Pef & & & 1 & & & & $1(1.6)$ \\
\hline & Pef-Amp & 1 & & & & & & $1(1.6)$ \\
\hline \multirow[t]{3}{*}{3} & Gen-Pef-Amp & & 1 & 1 & & 1 & & $3(4.8)$ \\
\hline & Pef-Etp-Cro & & & & & 1 & & $1(1.6)$ \\
\hline & Pef-Tet-Amp & & 1 & & & & & $1(1.6)$ \\
\hline \multirow[t]{5}{*}{4} & Pef-Nor-Tet-Amp & & & 1 & 1 & & & $2(3.2)$ \\
\hline & Gen-Etp-Amp-Mer & & & 1 & & & & $1(1.6)$ \\
\hline & Nor-Caz-Cro-Mer & 1 & & & & & & $1(1.6)$ \\
\hline & Gen-Pef-Tet-Amp & & 1 & & & & & $1(1.6)$ \\
\hline & Pef-Tet-Cro-Amp & & 1 & & & & & $1(1.6)$ \\
\hline \multirow[t]{5}{*}{5} & Gen-Pef-Tet-Cro-Amp & & & 1 & & & & $1(1.6)$ \\
\hline & Gen-Pef-Nor-Tet-Amp & & 1 & 1 & 2 & & & $4(6.3)$ \\
\hline & Gen-Pef-Etp-Cro-Amp & 1 & & & & & & $1(1.6)$ \\
\hline & Gen-Pef-Tet-Etp-Amp & 1 & & & & & & $1(1.6)$ \\
\hline & Gen-Pef-Tet-Caz-Amp & & & & 1 & & & $1(1.6)$ \\
\hline \multirow[t]{6}{*}{6} & Gen-Tet-Etp-Caz-Cro-Mer & & & 1 & & & & $1(1.6)$ \\
\hline & Gen-Pef-Etp-Caz-Cro-Amp & & & 1 & & & & $1(1.6)$ \\
\hline & Gen-Pef-Nor-Tet-Cro-Amp & 1 & & & & & & $1(1.6)$ \\
\hline & Gen-Pef-Tet-Caz-Cro-Amp & 1 & & & & & & $1(1.6)$ \\
\hline & Gen-Pef-Tet-Caz-Amp-Mer & 1 & & & & & & $1(1.6)$ \\
\hline & Gen-Pef-Nor-Etp-Cro-Amp & & & & & & 1 & $1(1.6)$ \\
\hline \multirow[t]{2}{*}{7} & Gen-Pef-Nor-Tet-Caz-Cro-Amp & 3 & 6 & 3 & 3 & & 1 & $16(25.4)$ \\
\hline & Gen-Pef-Nor-Tet-Etp-Cro-Amp & & 1 & & 1 & 1 & & $3(4.8)$ \\
\hline \multirow[t]{4}{*}{8} & Gen-Pef-Nor-Etp-Caz-Cro-Amp-Mer & & 1 & 1 & & & & $2(3.2)$ \\
\hline & Gen-Pef-Tet-Etp-Caz-Cro-Amp-Mer & & & & & 1 & & $1(1.6)$ \\
\hline & Gen-Pef-Nor-Tet-Etp -Caz-Cro-Amp & & & & 1 & & & $1(1.6)$ \\
\hline & Gen-Pef-Nor-Tet-Etp -Caz-Cro-Amp & 2 & & 1 & & & & $3(4.8)$ \\
\hline \multirow[t]{2}{*}{9} & Gen-Pef-Nor-Tet-Etp-Caz-Cro-Amp-Mer & 4 & 2 & 1 & & 2 & 1 & $10(15.9)$ \\
\hline & Total & & & & & & & 63 \\
\hline
\end{tabular}

Keys: Gen-Gentamicin, Pef-Pefloxacin, Nor-Norfloxacin, Tet-Tetracycline, Etp-Ertapenem, Caz-Ceftazidime Cro-Ceftriaxone, Amp-Ampicilin, Mer-Meropenem. K. pne- Klebsiella pneumoniae K. oxy- Klebsiella oxytoca P. vul- Proteus vulgaris E. col- Escherichia coli P. mir- Proteus mirabilis P. aer- Pseudomonas aeruginosa.

Table 7. Distribution of hemolytic patterns among bacteria

\begin{tabular}{|c|c|c|c|c|c|c|}
\hline Type of Haemolysis & $\begin{array}{c}\text { K. pneumonia } \\
(\mathrm{n}=17)\end{array}$ & $\begin{array}{l}\text { K. oxy } \\
(n=15)\end{array}$ & $\begin{array}{c}\text { P. vul } \\
(\mathrm{n}=14)\end{array}$ & $\begin{array}{l}\text { E. coli } \\
(\mathrm{n}=9)\end{array}$ & $\begin{array}{l}\text { P. mir } \\
(n=6)\end{array}$ & $\begin{array}{c}\text { P. aer } \\
(\mathrm{n}=3)\end{array}$ \\
\hline Beta & $3(17.7 \%)$ & $3(20.0 \%)$ & $4(28.6 \%)$ & $2(22.2 \%)$ & $1(16.7 \%)$ & $00.0 \%)$ \\
\hline Alpha & 3 (17.7\%) & - & $1(7.1 \%)$ & - & $2(33.3 \%)$ & - \\
\hline Non-Hemolytic & $11(64.7 \%)$ & 12 (80.0\%) & $9(64.3 \%)$ & $7(77.8 \%)$ & $3(50.0 \%)$ & $3(100.0 \%)$ \\
\hline
\end{tabular}

Table 8. Distribution of biofilm producers among isolates

\begin{tabular}{lccccc}
\hline Biofilm production & $\begin{array}{c}\text { K. pneumonia } \\
(\mathbf{n}=\mathbf{1 7})\end{array}$ & $\begin{array}{c}\text { K. oxy } \\
(\mathbf{n = 1 5 )}\end{array}$ & $\begin{array}{c}\boldsymbol{P} \text {. vul } \\
(\mathbf{n}=\mathbf{1 4})\end{array}$ & $\begin{array}{c}\text { E. coli } \\
(\mathbf{n}=\mathbf{9})\end{array}$ & $\begin{array}{c}\boldsymbol{P} . \text { mir } \\
(\mathbf{n}=\mathbf{6})\end{array}$ \\
\hline Strong & $6(26.6 \%)$ & $3(20 \%)$ & $6(42.9 \%)$ & $6(66.7 \%)$ & $3(50 \%)$ \\
Weak & $8(47.1 \%)$ & $8(53.3 \%)$ & $4(28.6 \%)$ & $2(22.2 \%)$ & $2(33.3 \%)$ \\
Non-biofilm & $3(17.7 \%)$ & $4(26.7 \%)$ & $4(28.6 \%)$ & $1(11.1 \%)$ & $2(66.7 \%)$ \\
\hline
\end{tabular}

\section{Discussion}

This study was carried out to determine the current prevalence of Gram-negative bacteria pathogens among patients suspected with UTI at the health center in EkitiState, Nigeria. Out of all the 122 urine samples collected within the stipulated study period, 64 (50.4\%) of the samples had significant bacterial growth by standard culture. Urinary tract infection is one of the most common infections in clinical and community settings and this finding in this present study conforms to this established fact about the epidemiology of UTIs. More specifically, significant bacteria appear to be more common among patients referred to the laboratory from the OPD, $\mathrm{A} / \mathrm{E}$ and $\mathrm{O} / \mathrm{G}$ units in the respective study locations, indicating that the community setting has a share of UTIs, as shown in this study. There is growing body of evidence that UTIs are getting more common in community settings with serious concerns that upsurge in the rate of community dependent UTIs could spread to clinical environments [27].

This study focused more specifically on the incidence of Gram-negative bacterial pathogens among individuals that presented symptoms of UTIs and who reported to the 
microbiology laboratory for prescribed urine culture and antibiotic sensitivity tests. Overall, the most common Gram-negative organism isolated from urine sample at the location was $K$. pneumonia, followed by $K$. oxytoca and $E$. coli. It should be noted that various studies have reported the prevalence of different bacterial pathogens at different periods. In a similar study by Agbagwa and Ifeanacho (2015) [10], K. pneumonia also appeared to be the most common organisms among patients with UTIs. However, bacterial etiologies of UTIs in clinical and community settings vary across different locations.

A closer observation of the overall antibiotic susceptibility shows that resistance to ampicllin was highest (94.5\%), followed by resistance to pefloxacin (87.3\%), gentamicin (85.5\%) and tetracycline (82.7). The organisms showed the highest susceptibility to meropenem (31.0\%) and ertapenem (40.0\%). The results also show that different organisms showed different proportions of antibiotic resistance to the different antibiotics, relative to the total number of each organism isolated and tested for antibiotic resistance. The high level of resistance shown to some of these antibiotics, especially ampicillin, agrees with other findings that have also reported elevated level of resistance to ampicillin and the $3^{\text {rd }}$ generation cephalosporins $[28,29]$. Another study by Leski et al., (2016) [6] reported widespread resistance to sulphonamides, chloramphenicol and gentamicin among Gram-negative bacteria isolated from patients with UTIs, although resistance to ampicilin was moderate. However, similar study [30] also reported low frequency of resistance to ampicillin and tetracycline. It should be noted that the etiologies of UTIs vary across different locations and clinical settings, so also is their susceptibility to antibiotics. Resistance to the carbapenems as observed in this study was lowest, and meropenem appears to be more sensitive than ertapenem. Reduced susceptibility to carbapenems are also increasingly reported even though for now, resistance among bacterial infections to carbapenems has not attained any crisis level but their presence is considered an emerging threat to health care (Eshetie et al., 2015). There are reports of increasing incidence of resistance to carbapenems in core clinical settings in Nigeria [31,32]. The bacteria also demonstrated diversity in their ability to resist multiple antibiotics of different groups.

In this study, resistance was defined as the reduced susceptibility to minimum of three antibiotics of different groups. Some of the bacteria showed resistance to as many as 6 different antibiotics. This observation has serious implication to healthcare and public health. Emergence of bacteria in clinical setting that show resistance to multiple antibiotics of different classes compromises the efficacy of the antibiotics and reduces the therapeutic options available for treatment of infectious diseases [33]. Another concern is that bacteria in clinical settings could develop resistance to carbapenems without prior history of usage of carbapenems for therapeutic purposes [34].

As noted in this study, resistance to third generation cephalosporins and production of extended spectrum beta -lactamase among bacteria in core clinical settings is currently a very serious challenge. The representative bacteria that were selected on the basis of their multidrug resistance phenotypes and their resistance to either ceftazidime or ceftriaxone were all confirmed to ESBL producers. This is because the $3^{\text {rd }}$ generation cephalsporins are currently one of the drugs of choice for the treatment of bacterial infections [35] and the dependence on this group of antibiotics could be a contributory factor to the emergence of resistance to these antibiotics. Some studies have also reported high frequency of ESBL producing bacteria in UTIs and healthcare associated infections in Nigeria [36,37]. A similar study in Bangladesh revealed that majority of the bacterial isolates from patients with UTIs was ESBL producers by double disk synergy test [38]. Latifpour et al., (2016) [39] also reported a high prevalence of ESBL producing $K$. pneumonia among individuals with healthcare and community acquired UTIs in Iran.

Also in this study, 27 bacterial isolates equivalent to $24.5 \%$ of the total bacterial isolates were confirmed to be hemolytic (Table 7). This indicates the potential pathogenicity of the bacterial isolates from patients with significant bacteriurea. The low frequency of hemolytic bacteria observed in this study is similar to the finding of Onanuga et al 2016 [40], who observed that approximately $13 \%$ of antibiotic resistant bacteria produced hemolysins. Many of the bacterial isolates were strong biofilm producers. Sixty six isolates (60.0\%) were strong biofilm producers while 43 (39.1\%) isolates were weak biofilm producers (Table 8 ). The ability of the bacteria to form biofilm enhances the capacity of such bacteria may aggregate to surfaces and catheters and cause persistent and recurrent bacterial infections. Bacteria that form biofilm during infections are very difficult to treat and require higher doses of antibiotics to eliminate such bacteria during treatment (Flores-Mireles et al., 2015). Continued exposure of bacterial biofilms to antibiotics enhances resistance to antibiotics used in the treatment.

\section{Conclusion}

Some patients observed in this study had UTI and bacteria isolated from their urine were resistant to antibiotics. Resistance to carbapenems appears to be and emerging issue. The general findings in this study further underscore the need for continuous surveillance of antibiotic resistant bacteria in healthcare and public health. This continuous surveillance will provide timely data for proper antimicrobial use and for antibiotic treatment policy for antimicrobial stewardship. There should be cautious use of the cephalosporins and necessary attention should be given to any emergence of carbapenems resistant bacteria in clinical settings. This is necessary to preserve the efficacy of the antibiotics that are commonly used for the treatment of infections in patients.

\section{Acknowledgements}

This is part of study funded by the Nigeria Tertiary Education Trust fund (TETFUND) Institutional Research Grant 2017. 


\section{References}

[1] Omonigho, S. E., Obasi, E. E. and Akukalia, R. N. (2001). In-vitro Resistance of Urinary Isolates of Escherichia coli and Klebsiella species to Nalidixic Acid. Nig. Jour Microbiol. 2001; 15(1): 25-29.

[2] Flores-Mireles, A., Walker, J. N., Capron, M. and Hultgreen, S. J. (2015). Urinary tract infections: epidemiology, mechanisms of infections and treatment options. Nature Rev Microbiol 13: 269-284.

[3] Stamm, W. E. and Norrby, S. R. (Urinary tract infections: disease panorama and challenges. Jour of Infect Dis 2001; 183 (Suppl 1): S1-S4.

[4] Tansarli GS, Athanasiou S and Falagas ME. Evaluation of antimicrobial susceptibility of Enterobacteriaceae causing urinary tract infections in Africa. Antimicroba Agents and Chemother 2013; 57(8): 3628-3639.

[5] Anozie OB, Lawani OL, Esike CUO, Mma E and Ajah LO. Prevalence and Common Microbial Isolates of Urinary Tract Infection in Pregnancy; A Four Year Review in a Tertiary Health Institution in Abakaliki, South-East Nigeria. Amer Jour Clin and Med Res 2016; 4(2), 25-28.

[6] Leski TA, Taitt CR, Bangura U, Stockelma, MG, Ansumana R and Cooper WH. High prevalence of multidrug resistant Enterobacteriaceae isolated from outpatient urine samples but not the hospital environment in Bo, Sierra Leone. BMC Infect Dis 2016; 16:167.

[7] Davidson S, Edwards CRW and Bouchier IAO. Principles and practice of medicine. Cambridge Press; 1989. p. 661.

[8] Ebie MY, Kandakai-Olukemi YT, Ayanbadejo J and Tanyigna KB. 2001. Urinary Tract Infections in a Nigerian Military Hospital. Nig Jour Microbiol 15 (1): 31-37.

[9] Oladeinde BH, Omoregie R, Olley M and Anunibe J. Urinary tract infection in a rural community of Nigeria. North Amer Jour Med Sci 2001; 3: 75-7.

[10] Agbagwa OE and Ifeanacho EJU. The Prevalence of UTI Pathogens in Urine Specimen Obtained from a Hospital in Rivers State Nigeria. Jour of Microbiol Res 2015; 5(5): 143-148.

[11] Obiogbolu CH, Okonko IO, Anyamere CO, Adedeji AO., Akanbi AO, Oguu AA, Ejembi J and Faleye TOC. Incidence of UTIs among pregnant women in Akwa metropolis SE Nigeria. Scientific Res and Essays 2012; 4(8): 820-824.

[12] Okonko IO, Ijandipe, L. A., Ilusanya, O. A., Donbraye-Emmanual, O. B., Ejembi, J. A., Udeze, A. O., Egun, O. B., Fowatade, A. and Nkang, A. O. (2009). Incidence of UTI among pregnant women in Ibadan, Southwest Nigeria. African Journal of Biotechnology 2009; 8(23): 6649-6657.

[13] Aiyegoro OA, Igbinosa OO, Ogunmwuyi IN, Odjadare EE, Igbinosa OE and Okoh AI. 2007. Incidence of urinary tract infections amng children and adolescents in Ile-Ife, Nigeria. African Jour Microbiol Res 2007; 013-019.

[14] Hanna-Wakim RH, Ghanem ST, El Helou MW, Khafaja SA, Shaker RA, Hassan SA, Saad RK, Hedari CP, Khinkarly RW, Hajar FM, Bakhash M, El Karah D, Akel IS, Rajab MA, Khour, and Dbaib, GS. Epidemiology and characteristics of urinary tract infections in children and adolescents. Frontiers Cellular Infection and Microbiology 2015; 5: 45.

[15] Tandogdu Z. and Wagenlehner FM. Global epidemiology of Urinary tract infections. Curr Opinion Infect Dis. 2016; 29(1): 73-79.

[16] Zalmanovici TA, Green H, Paul M, Yaphe J and Leibovici L. Antimicrobial agents for treating uncomplicated urinary tract infection in women.In Zalmanovici Trestioreanu Anca "Cochrane Database of Systematic Reviews". Cochrane Database of System Rev 2010; 10(10): CD00.7182.

[17] Dash M, Padhi S, Mohanty I and Parida B. Antimicrobial resistance in pathogens causing urinary tract infections in a rural community of Odhisa, India. Jour of Fam Comm Med 2013; 20 (1): $20-26$.

[18] Picozzi SC, Casellato S, Rossini M, Paola G, Tejada M, Costa E, Carmignani L. Extended-spectrum $\beta$-lactamase-positive Escherichia coli causing complicated upper urinary tract infection: urologist should act in time. Urol Ann 2014; 6:107-112.

[19] Bjorkman I, Berg J, Viberg N and Lundborg, C. S. Awareness of antibiotic resistance and antibiotic prescribing in UTI treatment: A qualitative study among primary care physicians in Sweden. Scand Jour Prim Healthcare 2013; 31: 50-55.

[20] Cerceo E, Deitelzweig SB, Sherman BM. and Ami, AN. Multidrug-Resistant Gram-Negative Bacterial Infections in the Hospital Setting: Overview, Implications for Clinical Practice, and Emerging Treatment Options. Microb.Drug Resist 2016; 22(5): 412-31.

[21] Kurtaran B, Candevir A, Tasova Y, Kibar F, Inal AS, Komur S. and Aksu, H. S. Antibiotic resistance in community-acquired urinary tract infections: prevalence and risk factors. Medical Science Monitoring 2010; 16(5): 246-51.

[22] Otajevwo FD and Amedu SS. 2015. Community acquired urinary tract infections prevalence in a tertiary institution based in Edo State, Nigeria. Glob Jour Med Res 15(3):11.

[23] Barrow GI and Feltham RKA. Cowan and Steel manual for identification of medical bacteria. 2003: 94-150.

[24] CLSI. Performance Standards for Antimicrobial Susceptibility Testing, Twentieth Informational Supplement. Wayne, PA, USA: Clinical and Laboratory Standards Institute; 2015.

[25] Tajbakhsh E, Ahmadi P, Abedpour-Dehkordi E, Arbab-Soleimani $\mathrm{N}$ and Khamesipour F. Biofilm formation, antimicrobial susceptibility, serogroups and virulence genes of uropathogenic $E$. coli isolated from clinical samples in Iran. Antimicrob Resis and Infect Cont 2016; 5: 11

[26] Ruiz J, Simo, K, Horcajada JP, Velasco M, Barranco M, Roig G, Moreno-Martínez A, Martínez JA, Jiménez de Anta T, Mensa J and Vila J. Differences in virulence factors among clinical isolates of Escherichia coli causing cystitis and pyelonephritis in women and prostatitis in men. Jour. of Clin Microbiol 2002; 40 (12): 4445-9.

[27] Erdem I, Kara R, Ardic E, Elbasan O, Mutlu R and Topaja AE. Community acquired lower urinary tract infections: Etiology, antimicrobial resistance and treatment results in female patients. Jour of Global Infect Dis 2018; 10(3): 129-132.

[28] Cunha MA, Assunção GL, Medeiros IM and Freitas, M. R. Antibiotic resistance patterns of urinary tract infections in a northeastern Brazilian capital. Revista do Instituto de Medicina Tropical de Sao Paulo 2016; 58: 2.

[29] Munkhdelger Y, Gunregjav NA, Dorjpurev A, Juniichiro N and Sarantuya J. Detection of virulence genes, phylogenetic group and antibiotic resistance of uropathogenic Escherichia coli in Mongolia. Jour of Infect Dev Countries 2017; 11(1): 51-57.

[30] Ali I, Rafaque Z, Ahmed S, Malik S and Dasti JI. Prevalence of multi-drug resistant uropathogenic E. coli in Potohar region of Pakistan. Asia Pacific Jour Trop Med 2016; 6(1): 60-66.1.

[31] Aliyu S. Carbapenemase producing Gram-negative bacteria: An emerging threat to healthcare in Africa. Annals of Nig Med 2013; 7: $1-2$.

[32] Anibijuwon II, Gbala, ID, Adebisi OO. Carbapenem-Resistant Enterobacteriaceae among In-Patients of Tertiary Hospitals in Southwest, Nigeria. Notulae Scientia Biologicae 2018; 10(3): 310-317.

[33] David H, Howard R, Scott D, Packard R and Jones D. The Global Impact of Drug Resistance. Clin Infect Dis 2003; 36: S4-S10.

[34] Yusuf I, Rabiu AT, Haruna M and Abdulahi SA. Carbapenems resistant Enterobacteriaceae (CRE) in intensive care units and surgical wards of hospitals with no history of of carbapenems usage in Kano, Northwest Nigeria. Niger Jour of Microbiol 2015; 27(1). 2612-2618.

[35] Bidell MR, Palchak M, Mohr J and Lodise TP. Fluoroquinolone and third-generation cephalosporin resistance among hospitalized patients with urinary tract infections due to Escherichia coli: do rates vary by hospital characteristics and geographic region? Antimicrob Agents Chemother 2016; 60:3170-3173.

[36] Ogefere HO, Aigbiremwen PA and Omoregie R. ExtendedSpectrum Beta-Lactamase (ESBL)-Producing Gram-negative Isolates from Urine and Wound Specimens in a Tertiary Health Facility in Southern Nigeria. Trop. Jour. Pharm Res 2015; 14 (6): 1089-1094.

[37] Giwa FJ, Ige OT, Haruna DM, Yaqub Y, Lamido TZ and Usman SY. Extended spectrum beta lactamase production and antimicrobial susceptibility pattern of uropathogens in tertiary hospital in Northwestern Nigeria. Annals of Trop Pathol 2018; 9: 11-16.

[38] Khan, S. A., Feroz, F. and Noor, R. Study of extended-spectrum b-lactamase-producing bacteria from urinary tract infections in Bangladesh. Tzu Chi Medical Journal 2013; 25: 39-42. 
[39] Latifpour M, Gholipour A and Damavandi MS. Prevalence of Extended-Spectrum Beta-Lactamase-Producing Klebsiella pneumoniae Isolates in Nosocomial and Community-Acquired Urinary Tract Infections. Jundishapur Jour Microbiol 2016; 9(3), e31179.
[40] Onanuga A and Selekere TL. Virulence and antimicrobial resistance of common urinary bacteria from asymptomatic students of Niger Delta University, Amassoma, Bayelsa State, Nigeria. Jour. Pharm Bioallied Sci 2016; 8(1), 29-33. 